\title{
The Effect of Service Quality on Customer Loyalty Mediated by Customer Satisfaction in Tourism Villages in Badung Regency
}

\author{
I Gusti Ngurah Surahman*, Putu Ngurah Suyatna Yasa and Ni Made Wahyuni \\ Magister of Management, Postgraduate Program, Universitas Warmadewa, Denpasar, Bali- \\ Indonesia \\ ngurahsurahman9@gmail.com
}

\begin{tabular}{|l|}
\hline \multicolumn{1}{|c|}{ Published: $30 / 03 / 2020$} \\
\hline How to cite (in APA style): \\
Surahman, I. G. N., Yasa, P. N. S., \& Wahyuni, N. M. (2020). The Effect of Service Quality on Customer Loyalty \\
Mediated by Customer Satisfaction in Tourism Villages in Badung Regency. Jurnal Ekonomi dan Bisnis Jagaditha, 7(1), \\
46-52. doi: https://doi.org/10.22225/jj.7.1.1626.46-52
\end{tabular}

\begin{abstract}
The aims of this research is to determine the effect of service quality with customer loyalty and customer satisfaction as a mediator between the relationship of service quality with customer loyalty. This research was collected data from 100 respondents who were customers who visited the Tourism Village in Badung Regency. The data were analyzed using structural equation modeling with partial least square approach. The results indicate an insignificant direct effect of service quality on customer loyalty. Significant direct influence on service quality with customer satisfaction, and customer satisfaction with customer loyalty. Furthermore, the results show an indirect effect between service quality and customer loyalty, which is mediated by customer satisfaction. The findings was empirically indicate that service quality has a negative effect on customer satisfaction. And customer satisfaction has a full mediating effect, customer satisfaction is important explaining the quality of service to drive customer loyalty. Based on the results it can be concluded that this research offers empirical evidence of the relationship of service quality, customer satisfaction and customer loyalty. This research makes a theoretical contribution to clarifying the high level of service quality increasing customer loyalty through customer satisfaction.
\end{abstract}

Keywords: Service quality, customer satisfaction, customer loyalty

\section{INTRODUCTION}

In the midst of competitive business competition there seems to be a changing trend in competition where various companies invest more to create loyal customers (Javed, 2017). This is very important to note because tourism is one of the businesses engaged in services, so visitor loyalty is a very important benchmark for the sustainability of its business (Akroush et al., 2016). Customer loyalty is the decisionmaking behavior to make a continuous purchase of the company's selected goods or services (Kajenthiran, 2018). Factors that influence customer loyalty are service quality factors (Chhabra, 2018) and customer satisfaction (Salome and Victor, 2014). Service quality is the result of a comparison between the services that are expected by customers and the services actually received by customers (Bhatta \& Durgapal, 2016). If the service received is lower than the desired expectation, the customer will feel disappointed and if the service received is higher than the desired expectation, the customer will feel satisfied (Alma, 2009). Quality of service namely reliability in service and speed of responding to customer complaints can significantly influence customer loyalty (Osarenkhoe, Komunda \& Byarugaba, 2015).

Quality of service, namely the clarity of estimated work time is able to have a positive and significant effect on customer intention to visit again (Issn et al., 2019). Based on previous research, there is a research gap that service quality has a significant negative effect on customer loyalty (Fernandes \& Solimun, 2018). The quality of Telkomsel's 
telecommunications industry services that have not met customer expectations, has led to reduced levels of customer loyalty. Customer satisfaction created by good service quality is able to have a significant positive effect on customer loyalty (Seesaiprai, 2016). Customer satisfaction on company services positively and significantly influences customer loyalty (Javed, 2017). The company's ability to meet customer expectations so as to create satisfaction that has a significant positive effect on customer intentions in returning visits (Bahadur, Aziz \& Zulfiqar, 2018). Perceived customer satisfaction from overall company services has been able to have a positive and significant effect on customer loyalty (Tripathi, 2018). Quality of service that is the ability to respond to customer complaints and complete service support facilities can have a positive and significant effect on customer satisfaction (Wantara, 2015). Service quality, namely the speed of responding to customer complaints and timely service has been able to have a significant positive effect on customer satisfaction (Subashini \& Gopalsamy, 2016). Thus, this research aims to determine the effect of service quality with customer loyalty and customer satisfaction as a mediator between the relationship of service quality with customer loyalty

\section{CONCEPT AND HYPOTHESES}

\section{Service quality}

Service quality is an important thing that should be maintained by all persons who being employee in certain company. Service quality is the extent of the difference between expectations and the reality of customers for the services they get (Etgar \& Galia, 2009). If the service received is lower than the desired expectation, the customer will feel disappointed and will stop his relationship with the service company (Alma, 2009). Service quality can thus be defined as the difference between customer expectations of service and service perception. If expectations are greater than performance, then perceived quality is less than satisfactory and hence customer dissatisfaction occurs (Bhatta \& Durgapal, 2016).

\section{Customer satisfaction}

In general, customer satisfaction is a feeling of pleasure or disappointment someone who appears after comparing the performance of the product results obtained with the expected performance. If performance is below expectations, then the customer becomes dissatisfied. If performance meets expectations, then the customer becomes very satisfied or happy (Nurmalina, 2017). Customer satisfaction with a product or service, is actually something that is difficult to obtain if the service company or industry does not really understand what customers expect. For products or services with the same quality, can provide different levels of satisfaction for different customers. Therefore, a company must always pay attention to the quality of products and services provided to customers (Subashini \& Gopalsamy, 2016).

\section{Customer loyalty}

Customer loyalty is a behavioral intention of buyers to maintain relationships with service providers (Sindwani \& Goel, 2015). The customer's willingness to use the company's products and services repeatedly over a long period of time and recommend the company's products and services to the surrounding environment. Customer loyalty is often associated with the customer's willingness to repeatedly buy goods or services that are accompanied by psychological ties and hold fast to the good of the company that supplies the goods and services (Ismail \& Yunan, 2015). Customer loyalty is an important element of the company, the success of the company's profitability is influenced by customers with the highest loyalty. Loyal customers are more attractive to companies because they tend to be less price sensitive and tend to repurchase company products (Sandada \& Matibiri, 2016).

\section{Quality of service and customer loyalty}

Based on research conducted by (Kaura, Prasad \& Sharma, 2015) on retail banking in India which states that service quality has a positive and significant effect on customer loyalty with assurance indicators that service providers can solve customer problems, ease of getting service. And supported by tangible dimensions, namely modern bank facilities, neat-looking bank employees. Able to significantly increase customer loyalty. (Akroush et al, 2016) research conducted on tourism in Jordan, found that service quality has a positive and significant effect on customer loyalty where the assurance dimension, namely the provision of experienced and competent tour guides, staff communicates in language that is easily understood, provides services with a high level of trust. And tangible dimensions, namely accommodation and good tourism facilities, good tourism infrastructure. Has been able to 
increase the interest of tourists to visit.

H1: Service quality has a positive and significant effect on customer loyalty.

Quality of service and customer satisfaction

In research of (Subashini \& Gopalsamy, 2016) quality of service namely internet banking services have been able to provide convenience to customer transactions and security of individual data that can be entrusted to the bank has been able to significantly increase customer satisfaction. Research conducted by (Jahmani, 2017) on the passenger service of Royal Jordanian airline which found that fast service quality to passengers was able to have a positive and significant effect on customer satisfaction and explained servqual indicators namely aircraft physical facilities, timely check-in procedures, willingness to help with problems passengers and confidence in the safety of this flight. Able to significantly influence passenger satisfaction.

H2: Service quality has a positive and significant effect on customer satisfaction.

\section{Customer satisfaction and customer loyalty}

Research conducted by (Javed, 2017) on the restaurant sector in Pakistan that found results that satisfaction positively and significantly affected customer loyalty, explained the variable service quality, consisting of speed of restaurant service, restaurant facilities in modern and complete Pakistan. Attractive interior of the building, good quality cuisine, varied food product innovations. Subsequent research carried out by (Tripathi, 2018) of the restaurant industry in Delhi India stated that satisfaction positively and significantly affected customer loyalty. Where explained the word of mouth variable that is the ability to persuade customers to give positive responses about this restaurant and convey it to others. So that raises customer satisfaction that is the visitor is satisfied with the cuisine of this restaurant and wishes to visit again.

H3: Customer satisfaction has a significant positive effect on customer loyalty.

\section{The mediating role of customer satisfaction}

Quality of service consisting of servqual methods, namely the company's physical building, and a complete service support facility can meet customer expectations. Quality of service that exceeds customer expectations creates customer satisfaction. Satisfied customers will visit again and use the company's products repeatedly (Wantara, 2015). Quality of service will be able to increase customer satisfaction, satisfied customers will use the company's products and services repeatedly over a long period of time. Satisfaction that occurs will continuously be able to realize customer loyalty. Loyal customers will speak positively about the company's products and recommend to friends and relatives (Shahid Iqbal, U1 Hassan \& Habibah, 2018).

H4: Customer satisfaction mediates the relationship between service quality and customer loyalty.

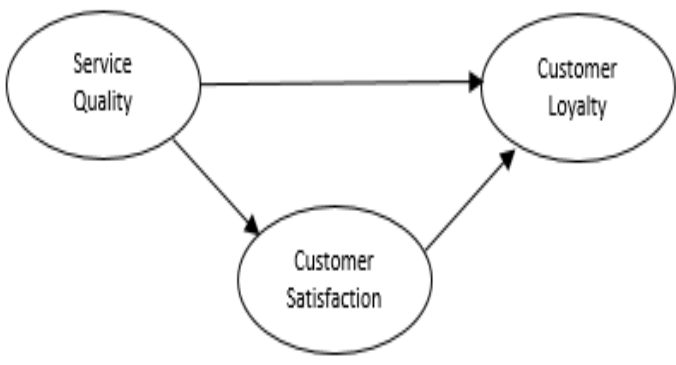

Figure 1

Concept Research Framework

\section{METHOD}

This research was conducted in a tourist village in Bali Badung regency, research data were collected through a survey method with a questionnaire instrument. This study collected data on 100 respondents, namely tourists visiting tourist villages in Badung Regency. With $60 \%$ male respondents and $40 \%$ female respondents, 65\% secondary education level, $8 \%$ diploma, 27\% Bachelor degree. Classification in the age of $17-30$ is $30 \%$, age $31-40$ is $40 \%$, age $41-50$ is $30 \%$. Then the questionnaire was analyzed by PLS analysis, the questionnaire measurement was modified in five-point Likert scale. This research was conducted empirically to evaluate the proposed framework by examining 4 hypotheses.

\section{RESULT AND DISCUSSION}

\section{Validity Test Result}

The reflective constructs of convergent validity in this study are shown in Table 1 . The instrument used in this study fulfills the validity criteria (convergent validity), because all construct indicators have correlation values exceeding 0.50 . Based on Table 2, it can be seen that building correlations with these indicators is higher than correlation indicators with other constructs. This shows that the latent construct of indicator predictions on 
their blocks is better than other block

indicators.

Table 1.

Convergent Validity

\begin{tabular}{|c|c|c|c|}
\hline Construct & Indicator & Correlation & Information \\
\hline \multirow{15}{*}{$\begin{array}{l}\text { Service } \\
\text { Quality } \\
\text { (X) }\end{array}$} & (Reliability) & \multirow{4}{*}{0,928} & \multirow{3}{*}{ Valid } \\
\hline & Timely operating hours (X1.1) & & \\
\hline & The tourist village helps with visitor problems (X1.2) & & \\
\hline & (Tangibles) & & \multirow{4}{*}{ Valid } \\
\hline & Visually attractive natural village touristic village (X2.1) & \multirow{3}{*}{0,910} & \\
\hline & Spacious and convenient parking facilities (X2.2) & & \\
\hline & (Assurance) & & \\
\hline & $\begin{array}{l}\text { Village tourism provides information needed by visitors } \\
\qquad(\mathrm{X} 3.1)\end{array}$ & \multirow{2}{*}{0,927} & \multirow{2}{*}{ Valid } \\
\hline & Village tourism prioritizes visitor safety (X3.2) & & \\
\hline & \multicolumn{2}{|l|}{ (Empathy) } & \multirow{4}{*}{ Valid } \\
\hline & Village tourism gives attention to visitors (X4.1) & & \\
\hline & $\begin{array}{l}\text { The tourist village pays attention to the comfort of visitors } \\
\text { (X4.2) }\end{array}$ & 0,908 & \\
\hline & (Responsiveness) & \multirow{3}{*}{0,938} & \\
\hline & The tourist village helps the needs of visitors (X5.1) & & \multirow{2}{*}{ Valid } \\
\hline & The tourist village tells the exact service time (X5.2) & & \\
\hline \multirow{5}{*}{$\begin{array}{c}\text { Customer } \\
\text { Satisfaction } \\
\text { (Y1) }\end{array}$} & Customer Satisfaction & & \\
\hline & The feeling of pleasure visiting this tourist village (Y1.1) & 0,943 & Valid \\
\hline & Visiting this tourist village exceeds expectations (Y1.2) & 0,922 & Valid \\
\hline & Feeling satisfied with the services provided (Y1.3) & 0,863 & Valid \\
\hline & Talk about positive things about this tourist village (Y1.4) & 0,870 & Valid \\
\hline \multirow{5}{*}{$\begin{array}{l}\text { Customer } \\
\text { Loyalty } \\
\text { (Y2) }\end{array}$} & Customer Loyalty & & \\
\hline & Customers return to visit this tourist village (Y2.1) & 0,974 & Valid \\
\hline & Customers do not consider other tourist villages (Y2.2) & 0,976 & Valid \\
\hline & $\begin{array}{l}\text { Customers recommend this attraction to friends or relatives } \\
\qquad \text { (Y2.3) }\end{array}$ & 0,965 & Valid \\
\hline & Customers try other objects in this tourist village (Y2.4) & 0,966 & Valid \\
\hline
\end{tabular}

Reliability Test Result

The construct can be stated to be reliable if the composite reliability value and alpha cronchbach are above 0.7 following smart PLS output shown in table 2 .

Tabel 2

Reliability Test Result

\begin{tabular}{cccc}
\hline No & Variable & $\begin{array}{c}\text { Cronbach's } \\
\text { Alpha }\end{array}$ & Information \\
\hline 1 & $\begin{array}{c}\text { Service } \\
\text { Quality (X) } \\
\text { Customer } \\
2\end{array}$ & 0,946 & Reliabel \\
& $\begin{array}{c}\text { Satisfaction } \\
\text { (Y1) } \\
\text { Customer } \\
\text { Loyalty } \\
\text { (Y2) }\end{array}$ & 0,914 & Reliabel \\
& 0,978 & Reliabel \\
\hline \hline
\end{tabular}

Jurnal Ekonomi dan Bisnis Jagaditha EISSN 2579-8162
The result of reliability output with Cronbach'h service quality is 0.946 , customer satisfaction is 0.914 , and customer loyalty is 0.978 which means all items are reliable because the value exceeds 0.70 (Latan \& Ghozali, 2012). Structural model testing is done by looking at the value of R-Square, which is suitable for the good of the model.

Statistical test results using PLS can be seen in Figure 1. Hypotheses 1 and 2 do not support the theory, and hypotheses 3 and 4 support the theory. 


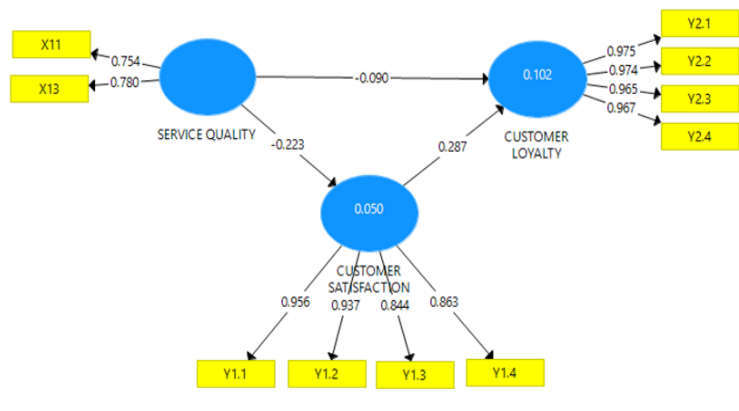

Figure 2

The complete model of the relationship between service quality, customer satisfaction, and customer loyalty

\section{Effect of service quality on customer loyalty.}

Service quality was found to be related to customer loyalty $(\beta=-0.90, p=0.413>0.05)$. The results of the study showed that the quality of service had a significant negative effect on customer loyalty with a value of -0.90 . This research revealed that the higher the quality of service, the lower the customer loyalty, but not significantly. The results of this study reject previous research by Akroush et al. (2016) research conducted on tourism in Jordan. Improved service quality from physical evidence of attractive natural landscapes, parking facilities and the convenience of attractions have not been able to increase customer loyalty, and the trend has decreased.

\section{Effect of service quality on customer satisfaction.}

Also found a direct effect of service quality on customer satisfaction $(\beta=-0.223$, $p$ $=0.05<0.10)$. The results of this study indicate that service quality has a significant negative effect on customer satisfaction. The results of this study reject previous research by Subashini and Gopalsamy (2016), The quality of services provided by tourism villages, timeliness of service, paying attention to visitors, unable to increase customer satisfaction and tend to experience a significant decrease.

\section{The effect of customer satisfaction on customer loyalty.}

The results showed that customer satisfaction had a significant influence on customer loyalty $(\beta=0.287, \mathrm{p}=0.002<0.05)$. The results showed that customer satisfaction had a positive and significant effect on customer loyalty. These results support Javed's previous research (2017) on the restaurant sector in Pakistan. Customer satisfaction created by the quality of service is able to remind customer loyalty in visiting tourist villages. Feeling happy when visiting and satisfaction with the services provided creates repeat visits from customers.

The role of customer satisfaction in mediating the influence of service quality on customer loyalty.

It was found that there was an indirect effect of service quality on customer loyalty through customer satisfaction $(\beta=0.510, p=$ $0.05)$. This means that customer satisfaction fully mediates the relationship between service quality and customer loyalty. This finding is able to explain the quality of service namely reliability and guarantee of increasing customer satisfaction, and then customer satisfaction has a significant influence on customer loyalty. Where to get customer loyalty, must be able to create customer satisfaction first.

\section{CONCLUSIONS}

This study offers empirical evidence about the relationship of service quality, customer satisfaction, and customer loyalty. Quality of service has a significant negative effect on customer loyalty. Service quality has a significant negative effect on customer satisfaction. Customer satisfaction has a positive and significant effect on customer loyalty. And customer satisfaction fully mediates the relationship between service quality and customer loyalty. This research makes a theoretical contribution to the role of service quality in increasing customer loyalty, through mediating customer satisfaction.

\section{REFERENCES}

Akroush, M. N. et al. (2016). Tourism service quality and destination loyalty - the mediating role of destination image from international tourists' perspectives', Tourism Review, 71(1), 18-44. Retrieved from https://doi.org/10.1108/TR-11-2014-0057

Alma, B. (2009) Manjemen Pemasaran dan Pemasaran Jasa, Cetakan kedelapan. Bandung: Alfabeta

Akpoyomare, O. B. E., Patrick, L. K. A., Salome, I. O., \& Victor, O. A. (2014). Determinants Of Customer Satisfaction And Loyalty In The Nigerian Telecommunications Industry. British Journal of Marketing Studies, 2(5), 67-83. Retrieved from http:// www.eajournals.org/wp-content/uploads/ Determinants-of-Customer-Satisfaction-andLoyalty-in-the-Nigerian-

Telecommunications-Industry.pdf

Bahadur, W., Aziz, S., \& Zulfiqar, S. (2018). Effect of employee empathy on customer satisfaction and loyalty during employee- 
customer interactions: The mediating role of customer affective commitment and perceived service quality. Cogent Business and Management. Cogent, 5(1), 1-21. Retrieved from https:// www.tandfonline.com/doi/

full/10.1080/23311975.2018.1491780?

scroll $=$ top\&needAccess $=$ true

Bhatta, K. R., \& Durgapal, B. P. (2016). Service Quality Perceptions and Customer Satisfaction in Nepalese Banking Sector. Indian Journal of Commerce \& Management Studies. 7(1), 17-23. Retrieved from https://www.researchgate.net/ publication/336719856 SERVICE QUALI TY PERCEPTIONS AND CUSTOMER

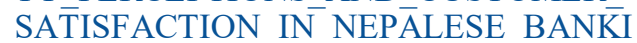
NG_SECTOR

Chhabra, K. (2018). Does Service Quality Matters in the Context of Internet Banking: A Perceptual Analysis of Indias Internet Banking Customers Perception Regarding Service Quality, Trust, Satisfaction and Loyalty. Journal of Commerce and Accounting Research. 7(3), 52-60. Retrieved from https://search.proquest.com/ docview/2024058062?pq-origsite= gscholar

Etgar, M., \& Fuchs, G. (2009). Why And How Service Quality Perceptions Impact Consumer Responses. Journal of Managing Service Quality. 19(4), 474-485. Retrieved from doi.org/10.1108/09604520910971566 https://

Fernandes, A. A. R., \& Solimun, S. (2018). The mediation effect of customer satisfaction in the relationship between service quality, service orientation, and marketing mix strategy to customer loyalty. Journal of Management Development, 37(1), 76-87. Retrieved from https://doi.org/10.1108/JMD -12-2016-0315

Hannan, S., Suharjo, B., Kirbrandoko., \& Nurmalina, R. (2017). The Influence of Customer Satisfaction , Trust and Information Sharing on Customer Loyalty of Professional Services Company: An Empirical Study on Independent Surveyor Services Industry in Indonesia. Abstract of Economic, Finance and Management Outlook, Conscientia Beam, 11(1), 344-353. Retrieved from .https://ideas.repec.org/a/ pkp/ecfmao/2016p9vol5.html

Ismail, A., \& Yunan, Y. S. M. (2015). Service Quality As a Predictor of Customer Satisfaction and Customer Loyalty. Logforum, 12(4), 269-283. Retrieved from http://yadda.icm.edu.pl/yadda/element/ bwmeta1.element.ekon-element000171442104

Issn, P. P. et al. (2019). Relationship of Service Quality and Consumer Loyalty: Moderating Role of Consumer Perception of Public Relationship Recent research calls to unfold the dynamics of consumer loyalty in the telecommunication sector. This study applies the public relation. 13(1), 25-31.

Jahmani, A. (2017). The effect of royal Jordanian airline service quality on passengers' satisfaction. International Journal of Business and Society, 18(S3), 519-530. Retrieved from http://www.ijbs.unimas.my/ images/repository/pdf/Vol18-s3-paper7.pdf

Javed, F., \& Cheema, S. (2017). Customer Satisfaction And Customer Perceived Value And Its Impact On Customer Loyalty. Journal of Internet Banking and Commerce, 22(58), 1-15. Retrieved from https:// www.semanticscholar.org/paper/CustomerSatisfaction-and-Customer-Perceived-Value -Javed-

Cheema/00a21eb6207aa45ff39f6c8bd5caf8a $596 \mathrm{e} 2232 \mathrm{~b}$

Kajenthiran, K. (2018). An Empirical Investigation on Retail Service Quality and Its Impact on Customer Loyalty in the Supermarkets in Jaffna District, Sri Lanka. Advances in Management and Applied Economics, SCIENPRESS Ltd, 8(1), 17-36. Retrieved from https://ideas.repec.org/a/spt/admaec/ v8y2018i1f8_1_2.html

Kaura, V., Prasad, C. S. D., \& Sharma, S. (2015). Service quality, service convenience, price and fairness, customer loyalty, and the mediating role of customer satisfaction. Marketing Intelligence and Planning, 33(4), 404-422. Retrieved from https:// doi.org/10.1108/IJBM-04-2014-0048

Osarenkhoe, A., Komunda, M. B. \& Byarugaba, J. M. (2015). Service quality: A mediator of customer complaint behaviour and customer loyalty. International Review of Management and Marketing, 7(1), 197-208. Retrieved from http://www.diva-portal.org/ smash/get/diva2:1089777/

FULLTEXT01.pdf

Sandada, M., \& Matibiri, B. (2016). An Investigation into the Impact of Service Quality, Frequent Flier Programs and Safety Perception on Satisfaction and Customer Loyalty in the Airline Industry in Southern Africa. South East European Journal of Economics and Business, 11(1), 41-53. Retrieved from https://doi.org/10.1515/jeb2016-0006

Seesaiprai, S. (2016). The Effects of Service Innovation and Service Quality on Customer's Loyalty in Small Service Enterprise: A Case Study on Car Care Business in Bangkok. Review of Integrative Business and Economics Research, 5(1), 296-306. Retrieved from https:// search.proquest.com/docview/1777508534? pq-origsite $=$ gscholar

Shahid Iqbal, M., Ul Hassan, M., \& Habibah, U. (2018). Impact of self-service technology (SST) service quality on customer loyalty and behavioral intention: The mediating role 
of customer satisfaction. Cogent Business and Management, 5(1), 1-24. Retrieved from https://www.tandfonline.com/doi/ full/10.1080/23311975.2018.1423770

Sindwani, R. \& Goel, M. (2015). The Impact of Technology based Self Service Banking Service Quality on Customer Loyalty. International Journal of Marketing and Business Communication, 4(3). Retrieved from https:/www.researchgate.net/ publication/279280743_The_Impact_of_Tec hnology_Based_Self_Service__Banking_Dim ensions_on Customer_Satisfaction

Subashini, R., \& Gopalsamy, V. (2016). A Review Of Service Quality And Customer Satisfaction In Banking Services: Global Scenario. Journal of Internet Banking and Commerce, 21(S5), 1-9. Retrieved from http://www.icommercecentral.com/openaccess/a-review-of-service-quality-andcustomer-satisfaction-in-banking-servicesglobal-scenario.pdf

Tripathi, G. (2018). Customer Satisfaction and Word of Mouth Intentions: Testing the Mediating Effect of Customer Loyalty. Journal of Services Research, 17(2), 1-16. Retrieved from https:/www.questia.com/ magazine/1P4-2013606929/customersatisfaction-and-word-of-mouth-intentions

Wantara, P. (2015). International Journal of Economics and Financial Issues The Relationships among Service Quality, Customer Satisfaction, and Customer Loyalty in Library Services. International Journal of Economics and Financial Issues, 5(5), 10-11. Retrieved from https:// www.semanticscholar.org/paper/The-

Relationships-among-Service-Quality\%2C-

Customer-

Wantara/1afd7708b43261c135374020e0fla 2422eea $15 \mathrm{e} 9$ 